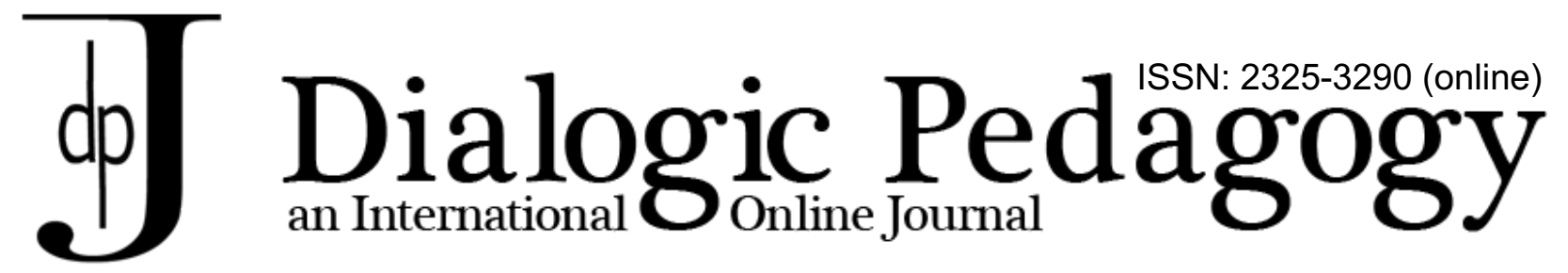

\title{
Social education through the lens of Bakhtinian theory
}

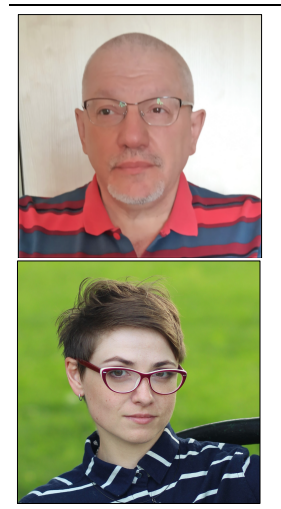

\section{Oleg Osovsky}

Mordovia State Pedagogical Institute,

Saransk, Russia

\section{Ekaterina Chernetsova}

National Research University Higher

School of Economics, Moscow, Russia

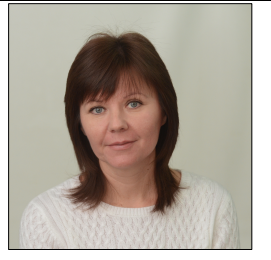

\section{Svetlana Dubrovskaya}

Mordovia State University,

Saransk, Russia

\begin{abstract}
A review of Bakhtin in the Fullness of Time: Bakhtinian Theory and the Process of Social Education, Edited by Craig Brandist, Michael E. Gardiner, E. Jayne White and Carl Mika. L.: Routledge. 2020. 160 p.

The review of the collection of articles Bakhtin in the Fullness of Time: Bakhtinian Theory and the Process of Social Education represents an analysis of the perspectives, main trends, and interpretations of key points, ideas, and concepts of M. M. Bakhtin in the contemporary theory and practice of Social Education.
\end{abstract}

The book's nine chapters are grouped within three problem areas, researched by the book's contributors. This is, in the first place, a re-establishment of those philosophical and sociological sources that trace back to the roots of Bakhtin's early views that had defined the nature of his responses to the challenges of his time in his early philosophical texts, books about Dostoevsky and books about bildungsroman. Another field of examination is Bakhtin's late dialogue with his contemporaries. Sometimes this dialogue is active and obvious, as it happens in the situation with the latest aesthetic and literary trends in Russia at the beginning of the 1920s. Sometimes this dialogue turns out to be ambiguous, therefore researchers can only guess how to reconstruct it, basing their views on the complementarity of Bakhtin's ideas and Lev Vygotsky or Paulo Freire's ones.

An equally important aspect of this collection is a number of articles devoted to how Bakhtin's theory is transformed into "classroom practice", whether it concerns the use of dialogue and its capabilities in interaction with foreigners, providing educational opportunities to the most economically vulnerable segments of South African society, or communication with preschoolers in kindergarten.

The authors of the book managed to create a convincing picture of how Bakhtinian theory is becoming one of the most important elements of contemporary theory and practice of education. At the same time, not only Bakhtinian ideas, primarily the concepts of dialogue, polyphony, carnival, and chronotope, are important, but also that free polyphony, which puts into effect any creative practice.

Keywords: Mikhail Bakhtin, dialogism, dialogic pedagogy, social education, carnival, polyphony, chronotope 
Oleg Osovsky works as a Chief research fellow in pedagogical institute in Saransk. He is a Dr. of Philology. Professor Osovsky is the author of several books on M. Bakhtin's ideas and their reception in AngloAmerican humanities, Russian emigre school in Europe.

Svetlana Dubrovskaya is a Professor in National Research Ogarev Mordovia State University. She specializes in Russian literature of the 19th-20th centuries, the scholarly legacy of M. M. Bakhtin, particularly, a study of the functioning of 'laughter' in Russian literary consciousness, and methods of teaching Russian as a foreign language. Professor Dubrovskaya has more than 100 academic and methodological publications.

Ekaterina Chernetsova is an Associate Professor in School of Foreign Languages at Higher School of Economics (Moscow). She specializes in American Studies and World Literature, problems of teaching languages and literature. Her research also focuses on contemporary American fiction, clash of paradigms in literature, and Bakhtinian approaches to a literary text. Her recent book is Chernetsova E. (2018) After New Journalism: History, Myth, Imagination in Norman Mailer's novels of the 1980s - 2000s.

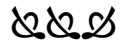

It might seem that the 125-th anniversary of Mikhail Bakhtin's birthday, one of the undoubtedly most established intellectuals of the modern humanities, should have become an occasion for a serious conversation both about the state of the field of humanities at the turn of the XX-XXI centuries, and about the main perspectives of their further development. A lot of new large-scale works about M.M. Bakhtin has appeared in recent years. Here, of course, it is necessary to mention recent collections edited by Matthias Freise (Freise, 2018), Gratchev \& Mancing (Gratchev \& Mancing, 2019) and the monographs published in Saransk (Dubrovskaya, 2019; Dubrovskaya, 2020) dedicated to the personality and legacy of Mikhail Bakhtin, and books by Vitaly Makhlin and Natalia Bonetskaya (see: Osovsky, 2017; Osovsky, 2018a, Osovsky, 2018b).

Yet, the question of what Bakhtin can still contribute to the modern humanities, what exactly of the great variety of his ideas, concepts and even terms is most adequately and most actively used by researchers today, is still relevant. Even the well-known books by Michael Holquist (Holquist, 1990) and Caryl Emerson (Emerson, 1997), where each of the authors tried to define what Bakhtinian dialogism is, how Bakhtin's reception has been developing in recent years both in his homeland and in the United States, as well as in other parts of the world - from China to Brazil - still do not fully answer the question of what is and where is Bakhtin's contribution in the contemporary academic knowledge. Recent books do not give a clear answer to this question either ${ }^{1}$. It seems that one of the instruments for determining the direction of the Bakhtinian contribution can be the notion of the "Bakhtin's filter" that we proposed a few years ago. The view of Bakhtin's ideas from the point of view of contemporary academic knowledge and the selection of the contemporary ideas most important for the development of Bakhtin's theory constitute the essence of this "Bakhtin's filter" (Dubrovskaya, Nesmelova, Osovskiy, 2019), that is, the framework and boundaries within which Bakhtin;s ideas and contemporary academic knowledge overlap and thereby the Bakhtinian contribution can be realized.

In this sense, a trend that has been taking shape for several decades could be quite revealing. From the late 1980 s - to the 2010 s, this trend is directly related to the use of Bakhtin's ideas in education

\footnotetext{
${ }^{1}$ The ongoing relevance of this issue can be evidenced by the 17th International Bakhtin Conference held in July 2021, among the participants of which were the authors of the book under review. As the speeches at the plenary sessions and panels demonstrated, the Bakhtin Studies Community is increasingly striving to articulate their understanding of the Bakhtin contribution to the contemporary academic knowledge, as V. Makhlin, C. Emerson, and K. B. M. Golubitsky, G. Tikhanov, G. Tulchinsky, E. Matusov, S. Barbato, M. Grodovsky, E. J. White and others spoke in their papers - https://bakhtin-conf.mrsu.ru/bakhtin2020/english/.
} 
(Matusov, 2007; Bibler, 2009; Solomadin \& Kurganov, 2009). Readers of DPJ are acquainted with the concept of "dialogic pedagogy." Moreover, books and articles on dialogic pedagogy that have appeared since the end of 2000 (Matusov, 2009; White \& Peters, 2011; Matusov E., Marjanovic-Shane, Gradovski, 2019.) greatly contributed to this. Within this trend, the book under review is getting even more remarkable and appealing.

Before we start a discussion about how its authors, representing a wide variety of countries and continents (from Great Britain and Canada to South Africa, Australia and New Zealand) understand Bakhtin's theory, let us turn our attention to the part of its title, the expression "in the fullness of time", as it best reflects the specifics of the approach taken in this book. The very emphasis on the concept of "in the fullness of time" as applied to the thinker who has devoted a considerable part of his research to "forms of time and chronotope" is not only self-explanatory, but also productive. Bakhtin's conception is presented in the book in its fullness, having been unfolded in time and space. And the swing to social education itself, is given in a quite Bakhtinian way - in synchrony and diachrony, involving the widest range of problems (folklore, literature, language, politics, economics, social institutions, etc.). In the book, the temporality is presented in two dimensions: in the contemporary transposition of Bakhtin's ideas into the language of pedagogy in the practice of modern education and in the historical reconstruction of the scholar's relationship with theories of education, his own pedagogical activity.

Thus, "Bakhtin in the classroom" discussed by some authors of the book is an issue related to the extent to which and how Bakhtin's key ideas can be applied in the classroom, that is, at school, university, etc., - an educational environment in the wide sense. In that sense, the modern pedagogical theories and practices that accept Bakhtin's ideas are mainly trying to raise this issue in one way or another. The advice that White \& Peters once suggested - "to read Bakhtin educationally" (White, Peters, 2011, p. 1) - underlies most of the articles in the volume.

Equally important here is Bakhtin's own biography and history as a real teacher in a real class, what he practiced intermittently from 1918 to the early 1960-s. Several articles regarding this issue have already been published in DPJ (Osovsky, Kirzhaeva, Chernetsova, Maslova, 2020; Laptun, \& Tihanov, 2018; Vasilyev, 2018).

In the book under review, it seems that this aspect of Bakhtin's practice has been described too narrowly: it is limited mainly to the time of Bakhtin's teaching in Saransk since 1945. "While Bakhtin's work has been widely received in educational studies in recent years, there is only one existing article on classroom practice that seems to have survived, and this does not really convey the sophistication of his cultural-historical works. This is probably because Bakhtin was steeped not in institutionally positioned pedagogical practice (though he taught in a pedagogical institute in the post-war period), but in a more general philosophy of culture in which the educational process was embedded in the process of becoming in Hegelian philosophy, generally known as Bildung" (p.1).

It should be recognized that chapter authors do not always draw clear lines. However, it should be noted that the global task to square the circle of Bakhtin's contribution to the academic knowledge is not the goal of the book. It seems to us that it is more important for them to outline a possible movement toward a better understanding of the processes that take place in education today, how they relate to Bakhtin's ideas, and where the routes to this understanding are. Perhaps if the book had originally been planned as a single project, the common positions of the authors would have been declared more explicitly, but we think it is more interesting for the reader to discover commonalities and disagreements among different contributors' interpretations of Bakhtin's ideas as they read through the chapters of the book. 
In this regard, at least a brief commentary would have been applicable to clarify the situation. Why does this seem important to us? Because, in our opinion, Bakhtin's pedagogical experience was much more diverse than just his work in a Soviet higher education during the "Stalinist night" (Emerson, 1997).

We want to emphasize that the traditional idea that Bakhtin's pedagogical practice begun in a small provincial Nevel in 1918 is not entirely accurate. The wife of Bakhtin's closest friend, philosopher Matvey Kagan, provided evidence about Bakhtin's considerable reputation as a tutor, a reputation he developed in Odessa even before the revolution, and that was further strengthened thanks to his tutoring practices in Petrograd and Vitebsk. In her interview, ninety-year-old Sofya Kagan recalled those days: "It happened that I had heard about Mikhail Mikhailovich Bakhtin even before I met him. When I was young I had a friend, Lelya Sochevanova, the daughter of a very rich, very big merchant. Their family had a tutor, teacher, coach - I don't know how to put it more precisely - engaged in education - Klebe, who came with the Sochevanovs from Germany. Then they lived for some time in Odessa, and this tutor met a very young 18-year-old Mikhail Mikhailovich, who was a tutor for Lelia Sochevanova's cousin, the daughter of another wealthy merchant, Rabinova. And so Klebe very often remembered Mikhail Mikhailovich and said with delight: "This is a genius! This is a genius!" He was astonished by the independence of judgment and breadth of knowledge of Mikhail Mikhailovich. He used to repeat: "This is a genius! This is a genius! "” (Pankov, 1995, p. 166).

Other evidence includes the publication of the well-known lectures of Bakhtin in the 1920s, as well as the materials of his training courses in 1937 and 1950s, the memoirs of former students and colleagues. All of these shape a multifaceted image of Bakhtin as a teacher and mentor (see, in particular: Yestifeyeva, 2000; Klyuyeva \& Lisunova, 2010; Laptun, 2020).

There is no doubt that the moral imperative that underlies Bakhtin's first published text, the article Art and Responsibility, represented views not only of Bakhtin the philosopher of culture, but Bakhtin the teacher and lecturer. In this respect, Bakhtin's skepticism toward "pedagogical dialogue" as one of the most unsophisticated invariants of this form of communication, which manifested itself by the end of the 1920s in the text Problems of Dostoevsky's Poetics, is all the more remarkable. The fact that Bakhtin retained this skepticism and even strengthened it in Problems of Dostoevsky's Poetics allows us to define this idea as one of the constants not only of the book about Dostoevsky itself, but also of Bakhtin's theory of dialogue: "In an environment of philosophical monologism the genuine interaction of consciousnesses is impossible, and thus genuine dialogue is impossible as well. In essence idealism knows only a single mode of cognitive interaction among consciousnesses: someone who knows and possesses the truth instructs someone who is ignorant of it and in error; that is, it is the interaction of a teacher and a pupil, which, it follows, can be only a pedagogical dialogue" (Bakhtin, 1984, p.81). Obviously, Bakhtin does not question the possibility of pedagogical communication, however, he considers it to be much more complex than a mere system of questions and answers between teacher and student. In fact, the authors of the book under review realize and acknowledge this "historical" side of Bakhtin's legacy: it is implicit in some chapters. Craig Brandist, for instance, who has a deep sense of the historical evolution of Bakhtin's basic concepts, and Jayne White and Michael A. Peters, who refer to the cultural history of Vitebsk in the 1920s, talk about it one way or another. But at the same time, Bakhtin is much more important for them less as a figure embedded in intellectual history of the twentieth century, than as an effective interlocutor, whose ideas make it possible to find urgent solutions to the problems of the twenty-first century. As the authors of the foreword point out, "In the post-2008 era, during which financial crises have morphed into global recession and which characterize growing social inequities, widespread political instabilities and further environmental decline and resource depletion, what is needed more than ever is a twenty-first century Bakhtin, one that is occupied with the distinct challenges our times present to all of us" (p. 3). 
The third decade of the XXI century brings similar challenges. Within the frame of the COVID-2019 the crisis of the existing traditional educational institutions has come to a total collapse. What is noticeable with the introduction of the new educational technologies, is a necessity to assess the pros and cons of distance learning.

We will not claim that these are confirmed intuitions and predictions, but to us the indisputable relevance of the book is obvious. To us, the justification of the authors' desire to place Bakhtin's theory in the broadest possible context of Western philosophy of culture and education is equally obvious. They are simultaneously emphasizing the fundamental principles of Bakhtin's philosophy, while not forgetting the pioneering nature of his thought. Accordingly, as stressed in the introduction, the book "takes Bakhtin's work to central stage in a targeted and critical manner by exploring central philosophical ideas in contemplation of their potential for education today. The sources for such endeavors are complex and draw from a much wider philosophical and disciplinary base than Bakhtin alone. This is necessary for at least two key reasons: First, because Bakhtin was influenced by a range of philosophical sources throughout his long life of writing and his works are sourced from fragments over time. Secondly, it is important to recognize that Bakhtin was not known first and foremost as an educationalist in a contemporary sense, and his work does not seek to specifically impose pedagogical instruction or commentary. Nonetheless, <...> dialogic philosophy has much to offer in the consideration of learning, relationships and what these aspects mean for contemporary society (p.1).

It should be noted that the book has a complicated history: the chapters of the book were originally published as independent articles in the journal Educational Philosophy and Theory from 2011 to 2017. Since then the authors have been engaged in an extended dialogue, which is another sign of the "fullness of time," The chapters are now a collection of articles by a team of colleagues who have brought their texts together under one book cover. The result is a metamorphosis not often seen in publishing practice: The idea of making a collection of articles transformed a relatively disparate set of texts written at different times into a single whole, which noticeably strengthened the persuasiveness of the authors' common conception.

The book's nine chapters reflect a variety of aspects of the "Bakhtinian shift" in the field of education and culture. For example, Craig Brandist in his chapter Bakhtinian Bildung and the Educational Process: Some Historical Considerations does not only identify the neo-Kantian paradigm of German intellectual thought as the most important source of Bakhtin's philosophy of culture. Although, both Hermann Cohen and Paul Natorp are important for Brandist, the views of human education that trace back to the postrevolutionary European ideas of the beginning of the 19th century, represented by Herder, von Humboldt and Hegel, are much more important for him. The vision of the development of human thought and nature offered by these thinkers across the dialectic of language and culture becomes fundamental to the image of European man in the bourgeois age. This vision is echoed in Bakhtin's arguments throughout his works on the novel of the 1930s.

Brandist's position is in many ways similar to that of Norman Franke. In his chapter Chronotopoi of the Good Life and Utopia: Bakhtin on Goethe's Bildungsroman Wilhelm Meister and the Carnivalesque Goethe is quite reasonably added to the already mentioned range of thinkers. The German writer is one of the most important characters in Bakhtin's history of the European novel of the Enlightenment. Moreover, Goethe's novel about Wilhelm Meister simultaneously becomes a powerful means of European education and, along with his other works, is directly involved in the pedagogical process, shaping the minds and behavior of a huge number of Europeans at the turn of the 18th and 19th centuries.

It should be added that Bakhtin's conception of a book on bildungsroman is extremely significant. It appeared in Bakhtin's most important biographical period, between the book on Dostoevsky, his first work 
on the novel, and the book on Rabelais. Here, Bakhtin, as illustrated in the third volume of his collected works (Bakhtin, 2012), articulates quite clearly his own view of personality development, which is much more consonant with the ideals of European pedagogical theory of the Enlightenment, rather than with the Stalinist pedagogy of the 1930s.

The experience of linguistic sociology and even political science is presented in even more expressive form in Michael E. Gardiner, Bakhtin and the 'general intellect.' Considering the importance of understanding the relationship between Bakhtin's ideas and contemporary Marxist theory, Gardiner believes that the range of ideas and concepts outlined by Bakhtin should find its place in the Marxist interpretation of the state and problems of social development in the early 21 st century. Interpretation of Bakhtin from the point of view of 'autonomist' Marxism is all the more remarkable because Bakhtin, as we know, was no stranger to the positions of Christian socialism. In "Big Time" of Bakhtinian social utopia, partly represented in his books on Dostoevsky and Rabelais, there was no place for reflections on economics, but the famous 1934 article Experience of Studying the Demand of Collective Farm Workers, written in the Kustanai exile, can well be regarded as a kind of supplement to what Gardiner writes about new forms of economy, including the economy of education.

It is hard to say how far from Bakhtin is Michael E. Gardiner in his understanding of general intellect and its role in changing the face of modern education, but the approach proposed in this chapter is quite in line with the trend of Bakhtin Studies which includes adapting key Bakhtinian notions and models to the problems of the modern world.

The forms of personalized dialogue not only with specific figures in the intellectual and educational history of the twentieth century, but also with whole movements are realized by the authors of this book in different ways. Sometimes it is Bakhtin's "indirect speech," revealed in his unvoiced dialogues with peers (like Vygotsky) or younger contemporaries (like Freire), sometimes with large-scale phenomena of which he himself was a witness or even a direct participant. This is precisely what E. Jayne White and Michael A. Peters present in detail in their chapter Bakhtin and the Russian Avant Garde in Vitebsk: Creative understanding and the collective dialogue.

As we know, having moved from provincial Nevel to the provincial center, Bakhtin found himself in the heart of the flourishing cultural life of the early revolutionary years. Among participants of this life in Vitebsk were artists Marc Chagall and Kazimir Malevich with their schools and followers. Intellectuals, their communist opponents and other witnesses and contributors to this interesting process, were the ones who made up Bakhtin's circle. This vibrant life, the polyphony of forms and methods and styles of revolutionary culture, with its searches and experiments in the theater, music, and pedagogy, and the active discussion of new discoveries in disputes and debates, could not but influence Bakhtin and his circle's perception of the new post-revolutionary culture, as the authors suggest. Let us clarify a few details: Chagall had left Vitebsk before Bakhtin arrived, and Malevich remained the main representative of the new art in Vitebsk, with whom, as we know, Bakhtin gave lectures in Vitebsk at the launch of the Union of Art Workers. One can strongly agree with the view of E. Jayne White and Michael A. Peters that it was in Vitebsk that Bakhtin first encountered the whole variety of forms of the revolutionary avant-garde. However, we should not forget that Bakhtin's experiences in Petrograd (1915-1917) included his intensive contacts not only with Symbolism and Acmeism ${ }^{2}$, but also with the Futurists and the future Formalists. However, it was in Vitebsk, in the relatively small space of a provincial town where everyone knew everyone and everyone was in contact with everyone all the time, that Bakhtin was probably able to feel the new atmosphere of art in the fullness of time. This is hardly the main argument for Bakhtin's rejection of formalism in his 1924 article and

\footnotetext{
2 "Acmeism, or the Guild of Poets, was a transient poetic school, which emerged in 1912 in Russia..." Wikipedia: https://en.wikipedia.org/wiki/Acmeist poetry
} 
subsequent texts, but the experience nonetheless made a contribution. Bakhtin's relations with Russian Formalism in the 1920s and early 1930s as well as with the Soviet Structuralism in the 1960s are complex and not limited to simply opposing them. Towards the end of Bakhtin's life, they transform into a kind of dialogue with Viktor Shklovsky, the Formalist and the semioticians Viacheslav Ivanov and Yury Lotman (Osovsky, Dubrovskaya, 2021).

From the dialogue with Suprematism and Formalism a reader flows logically to the dialogue between Bakhtin's ideas and those of Vygotsky and Freire. Needless to say, both of these names are quite expected in a book devoted to the educational dimension of Bakhtin's theory. In the chapter Bakhtinian Dialogic and Vygotskian Dialectic: Compatibilities and Contradictions in the classroom? Elizabeth Jayne White considers the two researchers alongside, adding a grounded comment on the difference in their approaches to psychology, although the shared comparative-historical and cultural-historical background of both thinkers is unquestionable. In White's version, the protomodernist Bakhtin opposes the pragmatist Vygotsky, but their understanding of "inner speech" and their perception of dialogue, if not identical, still are not contradictory. "Yet I conclude this article by suggesting that the consideration of both men's pedagogical provocations-both ontological and epistemological-have more to contribute to local and international schooling when interpreted against their philosophical origins" (p.87), White suggests, seeing in the consonances of this immanent dialogue an opportunity for a synthesis of Bakhtin and Vygotsky's ideas during class work.

Even more remarkable is the figure of Paulo Freire, author of his own version of dialogic pedagogy, which continues to play a significant role in the renovation of the educational paradigm in South America and Africa. This is exactly what Peter Rule points out in his chapter Bakhtin and Freire: Dialogue, Dialectic, and Boundary Learning, where the scale of the consonance between Bakhtin's dialogic theory and Freire's dialectics of dialogue is so great that the author is not disturbed by the fact that the Brazilian educator was most likely not familiar with the works of Bakhtin and the very consonance described by Peter Rule is determined more by the general trends of the era. However, there is one more circumstance which, we think, allows us to explain the proximity of Bakhtin's and Freire's understanding of dialogue. It is not only a common philosophical, religious and cultural framework based on the appreciation of Christian values and the traditions of European culture. Obviously, Bakhtin's understanding of dialogue, born on the material of Dostoyevsky, with his acute sympathy for the "humiliated and insulted", was inevitably in tune with Freire's "pedagogy of the oppressed" based on "liberation philosophy".

The chapters of the book directly related to pedagogical practice represent a noteworthy interest. Dialogic Ruptures: An Ethical Imperative by Sonja Arndt describes in detail a dialogue with another culture in the context of dealing with foreign students. The author's observations and the situations described are of undeniable practical value because they can easily be used in any other classroom with foreign students.

The pedagogical potential of laughter, the carnivalesque possibilities of humor, as Elizabeth Jayne White shows in her chapter Are You 'Avin a Laff? A pedagogical response to Bakhtinian carnivalesque in early childhood education proves to be a reliable tool in working with children in kindergarten. The absence of hierarchical relations between the adult and the child, the inner freedom of the very young child, his willingness to play provide a special carnivalesque space governed by the laws of the carnival. Despite the fact that considerable amount has been written about the pedagogical aspects of Bakhtin's theory of laughter and humor in general, White manages to look at the problem in a new perspective. We can add that among the instruments of "carnival teaching" in kindergarten and elementary school, Bakhtin's "word with a loophole" might well have found its place. The latter is echoed in the chapter Tawhiao's Unstated Heteroglossia: Conversations with Bakhtin with the multivalent semantics of the word in Maori. The analysis of the folklore utterances belonging to the legendary king allows Carl Te Hira Mika and Sarah-Jane Tiakiwai 
to speak about the internal polyphony of his sayings and about the possibility of their analysis, description and explanation in the work with students. Bakhtin's theory in connection with the study of folklore texts is another recognizable trend in Bakhtin Studies. On the one hand, Bakhtin himself was interested not only in European and Russian folklore, but also in Mordovian folklore (Dubrovskaya, 2020).

In conclusion, we note that the authors of the book have managed to create a convincing overview of how Bakhtin's theory is becoming one of the most important forces in today's theory and practice of education. It is not only Bakhtin's ideas themselves, most importantly the notions of dialogue, polyphony and carnival, but also the free polyphony necessary for any creative practice.

\section{References}

Bakhtin, M. (1984). Problems of Dostoevsky's poetics (c. Emerson, Ed.). Minneapolis: University of Minnesota Press.

Bakhtin, М. (2012) Бахтин М. М. Собрание сочинений: в 7 m. Т.3. М.: Языки славянских культур (Bakhtin M. M. Collected Works: in seven volumes). Vol. 3. M.: Languages of Slavic Cultures).

Bibler, V. (2009). The foundations of the School of the Dialogue Cultures rogram. // Journal of Russian and East European Psychology, 41(1), pp. $34-60$.

Brandist, C., Gardiner, M. E., White, E. Jayne, \& Mika, C. (Eds.). (2020). Bakhtin in the Fullness of Time: Bakhtinian Theory and the Process of Social Education. London: Routledge.

Dubrovskaya, S. (2020) М. М. Бахтин в литературной жизни Мордовии 1940-х -1960-е ге. (Bakhtin in literary life of Mordovia in the 1940-1960s) //Vestnik ugrovedenia = Bulletin of Ugric Studies. 2020; 10 (4): pp. 633-641.

Dubrovskaya, S. (Ed.). (2019) Михаил Михайлович Бахтин: проблемы изучения биографрии и научного наследия (Mikhail Mikhailovich Bakhtin: Problems of studying biography and academic heritage). Saransk: Mordovian University Press, 2019.

Dubrovskaya, S. (Ed.). (2020) Михаил Михайлович Бахтин: личность и наследие (Mikhail Mikhailovich Bakhtin: personality and heritage). Saransk: Mordovian University Press, 2020.

Dubrovskaya, S., Nesmelova O., Osovskiy O. (2019) «Литературоведение, в сущности, еще молодая наука...»: размышления над словарем русских литературоведов XX века ("Literary Study is a Relatively Young Discipline Still...": Reflections Over the Dictionary of Russian Literary Critics of the XX Century) // Filologicheskie Nauki. Nauchnye Doklady Vysshei Shkoly (Philological Sciences. Scientific Essays of Higher Education). 2019. №6. pp. 60-69.

Emerson, C. (1997). The First Hundred Years of Mikhail Bakhtin. Princeton. Princeton University Press, 1997.

Freise, M. (Ed.). (2018). Inspired by Bakhtin. Dialogic Methods in the Humanities. Boston: Academic Studies Press.

Gratchev, Slav N. \& Mancing, H. (Eds.), (2019). Mikhail Bakhtin's Heritage in Literature, Arts, and Psychology: Art and Answerability.

Holquist, M. (2002). Dialogism: Bakhtin and His World. 2nd Edition. L., N.Y.: Routledge.

Klyuyeva, I. V., \& Lisunova, L. M. (2010) М.М. Бахтин - мыслитель, педагог, человек (Bakhtin thinker, teacher, person). Saransk, 2010. 
Laptun, V. \& Tihanov, G. (2018). Pedagogical work of Mikhail M. Bakhtin (1920s-early 1960s) // Dialogic Pedagogy: An International Online Journal | http://dpj.pitt.edu DOI: 10.5195/dpj.2018.248 | 6, pp. 18-18.

Laptun, V. I. (2020) M. M. Bakhtin and A. A. Savitsky: years of working together at the Mordovian pedagogical institute in 1945 - 1950) // Center \& Periphery. 2020. №4. pp.86-93.

Matusov, E. (2007) Applying Bakhtin scholarship on discourse in education: A critical review essay // Educational Theory. Volume 57, Issue 2 p. 215-237. - 10.1111/j.1741-5446.2007.00253.x

Matusov, E. (2009). Journey into Dialogic Pedagogy. Hauppauge, NY: Nova Science Publishers.

Matusov, E., Marjanovic-Shane, A., \& Gradovski, M. (2019). Dialogic pedagogy and polyphonic research art: Bakhtin by and for educators, doi: 10.1057/978-1-137-58057-3. New York: Palgrave Macmillan.

Osovsky, О. (2017) Большое время идей: мышление М. М. Бахтина сквозь призму современности (The Big Time of Ideas: M. M. Bakhtin's Thinking through the Prism of Modernity) // Russian Literature. 2017.№1. pp. 252-253.)

Osovsky, О. (2018а) Филолог или фрилософ? Интеллектуальное «странничество» М. М. Бахтина: взгляд из 1990-х (Philologist or Philosopher? M. M. Bakhtin's intellectual "wanderlust": a view from the 1990s) // Russian Literature. 2018. № 1. pp. 250-251.

Osovsky, O. (2018b) The destinies of meta-criticism in the era of mega-crisis // Social Sciences. 2018. Vol. 49. № 2, P. 132-143.

Osovsky O., Kirzhaeva V., Chernetsova E., Maslova E. (2020). Education for Myself and Education for the Other: The Right to Freedom of Education and Mikhail Bakhtin's Experience // Dialogic Pedagogy: An International Online Journal | http://dpi.pitt.edu DOI: 10.5195/dpj.2020.346 | Vol. 8 (2020).

Osovsky, O., Dubrovskaya, S. (2021) Бахтин, Федин, Шкловский. Два малоизвестных эпизода из биографрии Михаила Бахтина (Bakhtin, Fedin, and Shklovsky. Two little-known episodes from Mikhail Bakhtin's biography) // Voprosy literatury. 2021 №1. pp. 191-216.

Pankov, N. A. (1995) О памятном, о важном, о былом... (устные воспоминания С.И. Каган и Ю.М. Каган) (About the memorable, about the important, about the past... (Oral Memoirs of S. I. Kagan and Y.M. Kagan)) //Dialog. The Carnival. Chronotop. 1995. № 2. C.165-181.

Solomadin, I. M. \& Kurganov, S. Y. (2009). The history of World Culture as Dialogue of Cultures. Middle and high school curricula journal of Russian \& East European Psychology, 47(2), 3 - 29.

Vasiliev N. M. (2018) M. M. Bakhtin as a university professor // Dialogic Pedagogy. Vol.6. P. T1-T7. DOI: $\underline{10.5195 / \mathrm{dpj} .2018 .234}$

White E.J. \& Peters M.A. (Eds.), Bakhtinian Pedagogy: Opportunities and Challenges for Research, Policy and Practice in Education Across the Globe. New York, NY: Peter Lang, 2011. XII, 272 p.

Yestifeyeva, V. B. (2000) Воспоминания о Бахтине (Первое десятилетие в Саранске) (Метоries of Bakhtin (The first decade in Saransk)) // Dialog. Carnaval. Chronotop. 2000. №1. pp.127-151. 


\section{(c) $\mathbf{E Y}$}

New articles in this journal are licensed under a Creative Commons Attribution 4.0 United States License.

\section{UILIS}

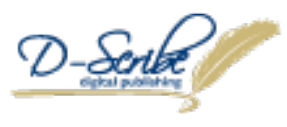

This journal is published by the University Library System, University of Pittsburgh as part of its D-Scribe Digital Publishing Program and is cosponsored by the University of Pittsburgh Press. 